\title{
Satu kasus nekrolisis epidermal toksik yang diduga disebabkan oleh kotrimoksasol
}

\author{
${ }^{1}$ Ellen Gunawan \\ ${ }^{1}$ Anthony S. Wibawa \\ ${ }^{2}$ Pieter L. Suling \\ ${ }^{2}$ Nurdjannah J. Niode
}

\author{
${ }^{1}$ Program Studi Ilmu Penyakit Kulit dan Kelamin Fakultas Kedokteran \\ Universitas Sam Ratulangi Manado \\ ${ }^{2}$ Bagian Ilmu Kesehatan Kulit dan Kelamin Fakultas Kedokteran \\ Universitas Sam Ratulangi Manado \\ Email: keziaellengunawan@gmail.com
}

\begin{abstract}
Toxic epidermal necrolysis (TEN) is an acute life-threatening muco-cutaneous reaction, characterized by extensive necrosis and detachment of the epidermis (>30\% BSA). Drugs are often suspected as the main cause, one of which is trimethoprim- sulfamethoxazole (TMP-SMX). Management includes immediate termination of alleged drugs, supportive treatment such as maintenance of electrolyte balance, nutrition, analgesics, antibiotics and specific treatment of immunosuppressants with dexamethasone injection. We reported a female 36 yo who complained of dark red spots and flaky skin on the face, chest, abdomen, back, arms, and genitals associated with fever, dysphagia, and sore eyes. There was a history of cotrimoxazole consumption prior to the rashes. Skin examination revealed multiple, well defined, erythematous macula, numular to plaque-sized, multiple bullae, purpura, erosion, crusts, and epidermolysis on the face, chest, abdomen, back, and upper extremities. Patient also had vulval erosion and conjunctival hyperemia. Laboratory tests showed total protein $6.5 \mathrm{~g} / \mathrm{dL}$ and albumin $3.2 \mathrm{~g} / \mathrm{dL}$. Patient was treated with intravenous RL:D 5\%: $\mathrm{NaCl} 0.9 \%=1: 1: 120 \mathrm{gtt} / \mathrm{min}$, ranitidine injection 2x25 mg IV, ceftriaxone injection 1x2 gr IV, $\mathrm{NaCl} 0.9 \%$ moist dressing 3x30 minutes on erosions, polymyxin B sulphate, neomycin sulphate and dexamethasone eye drops 4x1gtt, artificial tears 6x1gtt, and tapered dexamethasone injection 4x10 mg IV. Diagnosis of TEN was established through anamnesis, physical examination, and laboratory examination. Patient showed clinical improvement within 2 weeks after the discontinuation of cotrimoxazole, and administration of supportive and specific treatment.
\end{abstract}

Keywords: toxic epidermal necrolysis, cotrimoxazole

\begin{abstract}
Abstrak: Nekrolisis epidermal toksik (NET) merupakan reaksi mukokutan akut yang mengancam jiwa, ditandai nekrosis dan pelepasan epidermis yang luas (>30\% LPB). Obat diduga sebagai penyebab utama, salah satunya ialah golongan trimetoprim-sulfametoksazol (TMPSMX). Penatalaksanaan meliputi penghentian segera obat yang diduga penyebab, penanganan suportif (keseimbangan elektrolit, nutrisi, analgetik, antibiotik) dan pengobatan spesifik (imunosupresan deksametason injeksi). Kami melaporkan kasus seorang perempuan 36 tahun dengan bercak merah kehitaman dan kulit terkelupas di wajah, dada, perut, punggung, kedua lengan, dan kelamin disertai demam, nyeri menelan, dan kemerahan pada mata. Riwayat konsumsi kotrimoksazol sebelum timbul ruam. Status dermatologikus: pada wajah, dada, perut, punggung, kedua lengan atas dan bawah terdapat makula eritematosa, batas tegas, multipel, ukuran numular-plakat; bula, purpura, erosi, krusta, dan epidermolisis. Terdapat erosi vulva erosi dan konjungtiva hiperemis bilateral. Pemeriksaan laboratorium: protein total $6,5 \mathrm{~g} / \mathrm{dL}$ dan albumin 3,2 g/dL. Penanganan berupa IVFD RL:D 5\%:NaCl 0.9\% = 1:1:1 20 tetes $/$ menit, injeksi ranitidin 2x25 mg IV, injeksi seftriakson 1x2 gr IV, kompres terbuka $\mathrm{NaCl} 0,9 \% 3 \times 30$ menit (luka), obat tetes mata (polimiksin B sulfat, neomisin sulfat dan deksametason) 4x1 tetes, air
\end{abstract}


mata buatan 6x1 tetes dan injeksi deksametason 4x10 mg IV yang diturunkan secara bertahap sesuai perbaikan klinis. Diagnosis NET pada kasus ini ditegakkan berdasarkan anamnesis, pemeriksaan fisik, dan pemeriksaan penunjang. Keadaan umum pasien membaik dalam 2 minggu setelah dilakukan penghentian obat yang diduga penyebab, penanganan suportif, dan pengobatan spesifik.

Kata kunci: nekrolisis epidermal toksik, kotrimoksazol

Nekrolisis epidermal toksik (NET) dan sindroma Steven-Johnson (SSJ) merupakan reaksi mukokutan akut yang mengancam nyawa, ditandai dengan nekrosis dan pelepasan epidermis yang luas. ${ }^{1}$ Kedua penyakit ini mirip dalam hal gejala klinis dan histopatologik, faktor risiko, serta penyebab dan patogenesis, sehingga saat ini digolongkan dalam proses yang identik dan hanya dibedakan berdasarkan keparahan saja. Pada SSJ, terdapat epidermolisis sebesar $<10 \%$ luas permukaan badan (LPB), sedangkan pada NET $>30 \%$. Keterlibatan 10-30\% LPB disebut sebagai overlap SSJ-NET. ${ }^{2}$

Nekrolisis epidermal toksik jarang terjadi dengan insidensi 0,4-1,2 kasus/1 juta penduduk/tahun dan angka kematian 25$35 \%$. ${ }^{2,3}$ Jumlah pasien NET/SSJ yang dirawat di Bagian Kulit dan Kelamin RSUP Prof. Dr. R. D. Kandou Manado periode Januari 2012 sampai Desember 2014 sebanyak 11 orang. 4

Etiologi dan patogenesis dari NET belum diketahui dengan jelas. Saat ini obat dianggap sebagai penyebab utama. Telah dilaporkan lebih dari 100 obat-obatan dapat menjadi penyebab terjadinya nekrolisis epidermal. Golongan obat yang memiliki risiko tinggi antara lain antibakterial sulfonamid, antikonvulsan, alopurinol, obat anti inflamasi non-steroid (OAINS), lamotrigin, dan nevirapin. ${ }^{1,5}$

Penatalaksanaan yang optimal untuk kasus NET membutuhkan diagnosis tepat sejak awal, penghentian segera obat yang diduga penyebab, penanganan suportif, dan pengobatan spesifik. ${ }^{1,6}$ Prognosis NET dapat diperkirakan berdasarkan SCORTEN (Severity of illness Score for Toxic Epidermal Necrolysis). ${ }^{2,3,7}$

Berikut ini dilaporkan satu kasus nekrolisis epidermal toksik (NET) yang diduga disebabkan oleh kotrimoksasol.

\section{LAPORAN KASUS}

Seorang perempuan, 36 tahun, datang ke Poliklinik Kulit dan Kelamin RSUP Prof. Dr. R. D. Kandou Manado dengan keluhan bercak merah kehitaman dan kulit terkelupas di wajah, dada, perut, punggung, kedua lengan, dan kelamin. Awalnya bercak kemerahan timbul di perut dan punggung kemudian meluas ke wajah, dada, kedua lengan, dan kelamin, diikuti dengan terbentuknya lepuh yang mudah pecah dan kulit terkelupas. Empat hari sebelum timbul bercak pasien mengalami demam disertai diare lalu berobat ke dokter dan diberi pengobatan berupa kotrimoksasol, parasetamol, cetirizine, dan metalprednisolon. Enam jam setelah meminum obat tersebut pasien mengeluh timbul bercak kemerahan di perut dan punggung yang meluas ke wajah, dada, kedua lengan, dan kelamin, diikuti kulit terkelupas. Keluhan disertai nyeri menelan dan mata yang tampak kemerahan. Pasien menyangkal adanya demam, nyeri berkemih, dan nyeri saat buang air besar. Pasien dirawat di rumah sakit setempat dengan pengobatan berupa injeksi metilprednisolon, ranitidin, cetirizine, kloramfenikol salep mata, dan bioplasenton krim. Setelah mendapatkan perawatan selama 3 hari, kondisi pasien tidak membaik dan akhirnya dirujuk ke RSUP Prof. Dr. R. D Kandou.

Pada pemeriksaan fisik didapatkan keadaan umum pasien tampak sakit berat, kesadaran kompos mentis, tekanan darah $110 / 70 \mathrm{mmHg}$, nadi $68 \mathrm{x} /$ menit, pernafasan $22 \mathrm{x} / \mathrm{menit}$, dan suhu $36,2^{\circ} \mathrm{C}$. Tinggi badan $158 \mathrm{~cm}$, berat badan $55 \mathrm{~kg}$, kesan gizi cukup. Pada pemeriksaan toraks dan abdomen tidak didapatkan kelainan. Status 
dermatologikus: Regio fasialis, torakalis anterior et posterior, abdominalis, brakialis et antebrakialis dekstra et sinistra makula eritematosa, batas tegas, multipel, ukuran numular-plakat, disertai bula, purpura, erosi, krusta, dan epidermolisis; regio orbitalis dekstra et sinistra: konjungtiva hiperemis bilateral; regio labia oris superior et inferior: adanya erosi dan krusta kehitaman; regio genitalia: terdapat erosi.

Pada hasil pemeriksaan laboratorium didapatkan kadar hemoglobin 13,6 g/dL, leukosit 3600/uL , trombosit $279.000 / \mathrm{mm}^{3}$, protein total $6,5 \mathrm{~g} / \mathrm{dL}$, natrium $136 \mathrm{mEq} / \mathrm{L}$, kalium 3,8 $\mathrm{mEq} / \mathrm{L}$, klorida $99 \mathrm{mEq} / \mathrm{L}$.

\section{Hari ke-1 perawatan}
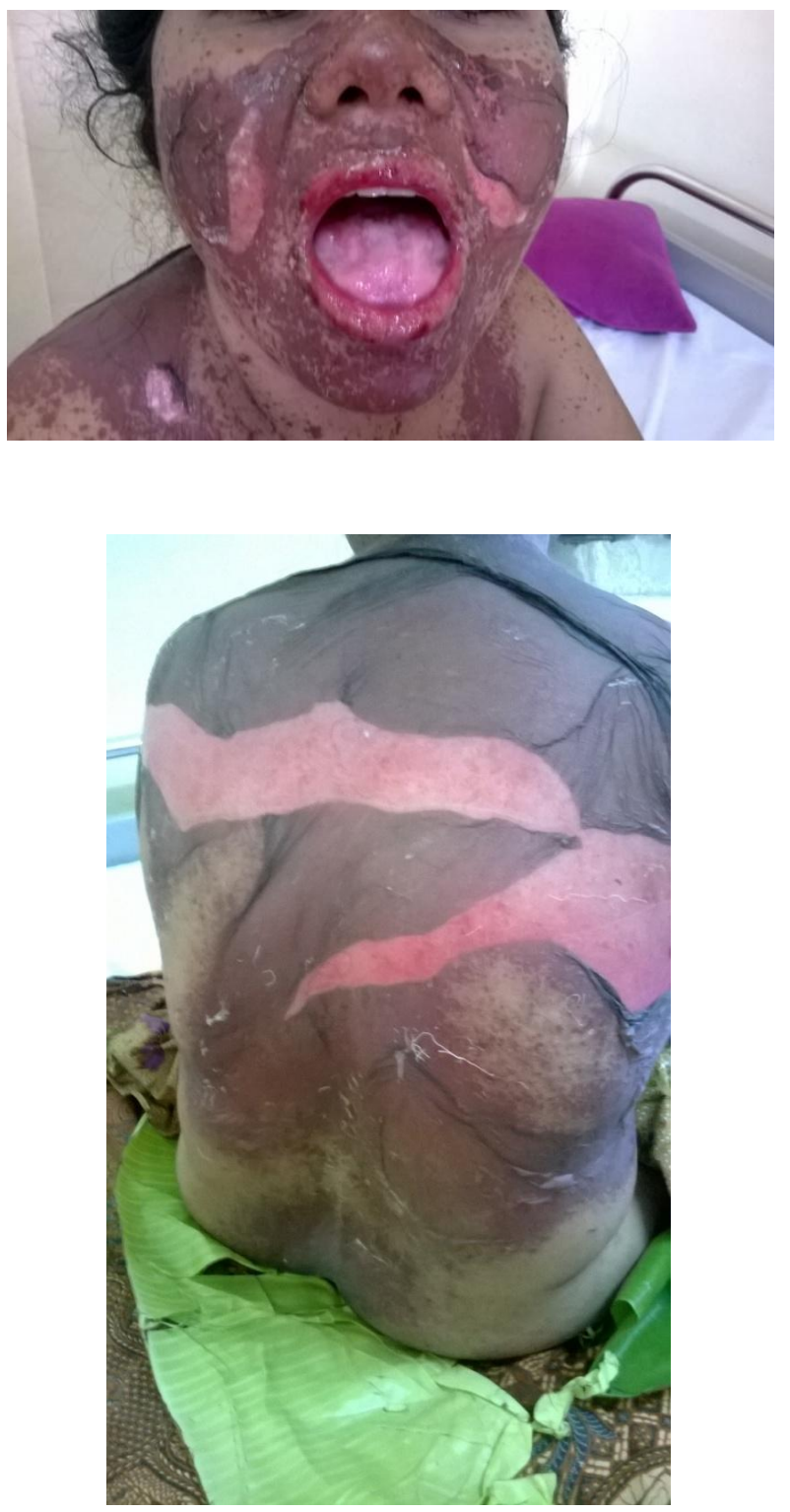

Pasien dikonsulkan ke Bagian Ilmu Penyakit Mata dan didiagnosis sebagai konjungtivitis dan ke Bagian Ilmu Penyakit THT-KL dan didiagnosis sebagai mukositis orofaring.

Penatalaksanaan pada kasus ini ialah diberikan IVFD RL:D 5\%: $\mathrm{NaCl} 0,9 \%=1$ : 1:1 20 tetes/menit, injeksi ranitidin $2 \times 25$ mg IV, injeksi seftriakson $1 \times 2$ gr IV, kompres terbuka $\mathrm{NaCl} \quad 0,9 \% \quad 3 \times 30$ menit (luka), dan injeksi deksametason 4x10 mg IV yang diturunkan secara bertahap sesuai perbaikan klinis. Dari bagian Ilmu Penyakit Mata diberikan Cendo lyteers ${ }^{\circledR}$ 6x1tetes ODS dan Polydex ${ }^{\circledR} 4 x 1$ tetes ODS.

\section{Hari ke-13 perawatan}

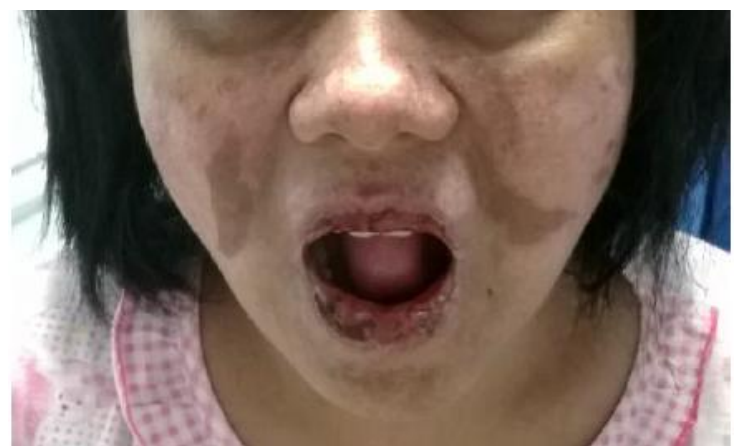

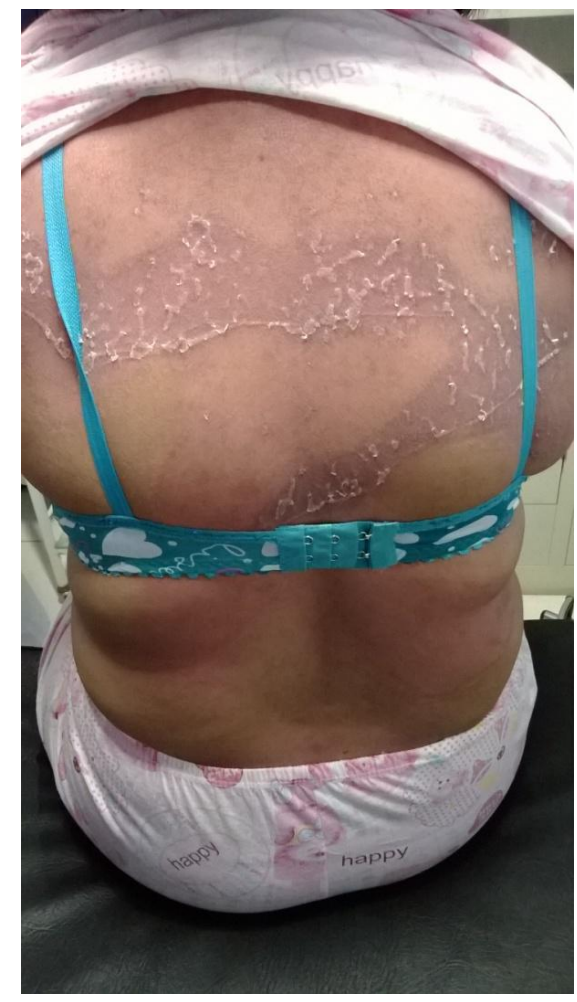




\section{BAHASAN}

Pada kasus ini, diagnosis NET ditegakkan berdasarkan anamnesis, pemeriksaan fisik, dan pemeriksaan penunjang.

Pada anamnesis didapatkan keluhan timbulnya bercak merah kehitaman dan kulit terkelupas di wajah, dada, perut, punggung, kedua lengan, dan kelamin sejak 4 hari sebelum pasien datang ke rumah sakit. Awalnya bercak kemerahan timbul di perut dan punggung kemudian meluas ke wajah, dada, kedua lengan, dan kelamin, diikuti dengan terbentuknya lepuh yang mudah pecah dan kulit terkelupas. Empat hari sebelum timbul bercak pasien mengalami demam disertai diare, berobat ke dokter dan diberikan pengobatan berupa kotrimoksasol, parasetamol, cetirizine dan metilprednisolon. Enam jam setelah meminum obat tersebut pasien mengeluh timbul bercak kemerahan di perut dan punggung yang meluas hampir di seluruh tubuh diikuti kulit terkelupas. Keluhan tersebut disertai nyeri menelan dan mata yang tampak kemerahan. Kotrimoksasol diduga kuat sebagai penyebab timbulnya NET pada pasien ini. Kemungkinan parasetamol menjadi penyebab timbulnya NET kecil karena obat ini merupakan obat yang biasa dikonsumsi oleh pasien dan tidak menimbulkan keluhan.

Berdasarkan hasil pemeriksaan pada pasien ini, ditemukan makula eritematosahiperpigmentasi, purpura, dan erosi pada wajah, dada, punggung, perut, kedua lengan, dan kelamin disertai krusta kehitaman pada bibir. Konjungtiva bilateral tampak hiperemis tanpa disertai sekret. Terdapat epidermolisis lebih dari $30 \%$ luas permukaan tubuh sehingga pasien ini didiagnosis sebagai nekrolisis epidermal toksik (NET).

Pada pemeriksaan laboratorium penderita NET bisa didapatkan ketidakseimbangan elektrolit, hipoalbuminemia, hipoproteinemia, renal azotemia, anemia, leukositosis ringan, dan trombositopeni. ${ }^{1}$ Hasil pemeriksaan laboratorium awal pada pasien ini didapatkan penurunan kadar protein sebesar $6,5 \mathrm{~g} / \mathrm{dL}$ dan albumin 3,2 $\mathrm{g} / \mathrm{dL}$. Pasien disarankan untuk diet putih telur 2 butir /hari. Pada pemeriksaan ulangan 1 minggu kemudian terdapat perbaikan kadar protein total menjadi 6,7 $\mathrm{g} / \mathrm{dL}$ dan albumin $3,3 \mathrm{~g} / \mathrm{dL}$.

Gambaran histopatologik NET berupa apoptosis epidermal yang berkaitan dengan degenerasi hidropik sel basal atau vesikulasi subepidermal. Terdapat eksositosis limfosit dan nekrosis sel satelit. Epitel kelenjar keringat dan folikel rambut juga terkena, tetapi lebih jarang. Terdapat infiltrat perivaskular dari limfosit, makrofag, dan melanofag pada bagian superfisial dermis, yang kadang disertai edema. Kadang-kadang dapat ditemukan eosinofil. ${ }^{8}$ Pada pasien ini tidak dilakukan biopsi kulit untuk pemeriksaan histopatologik karena riwayat dan lesi klinis berupa epidermolisis yang mengenai $30 \%$ luas permukaan tubuh sudah jelas.

Prinsip penanganan NET ialah penghentian konsumsi obat yang dicurigai sebagai penyebab, penanganan suportif yaitu mempertahankan status hemodinamik seperti keseimbangan elektrolit, nutrisi, pemberian analgetik, keseimbangan cairan, antibiotik, nutrisi adekuat, suhu lingkungan, dan perawatan kulit yang tepat ${ }^{1,6,7}$ serta penanganan spesifik seperti pemberian imunosupresan. ${ }^{1}$ Keseimbangan elektrolit dan cairan dapat dipertahankan dengan pemberian infus berupa dekstrose $5 \%, \mathrm{NaCl}$ 0,9\%, dan Ringer laktat perbandingan 1:1:1 dalam 1 labu yang diberikan 8 jam sekali. ${ }^{9}$ Penggunaan kortikosteroid sistemik masih kontroversial. ${ }^{1,10}$ Pemberian kortikosteroid diyakini dapat menekan inflamasi dan nekrosis keratinosit. ${ }^{7}$ Sebuah studi retrospektif yang dilakukan oleh Roongpisuthipong et al. ${ }^{11}$ di Rumah Sakit Vajira Bangkok pada tahun 2014 menunjukkan bahwa pemberian kortikosteroid sistemik jangka pendek dapat menurunkan angka mortalitas pada kasus NET tanpa meningkatkan risiko infeksi sekunder. Berdasarkan panduan pelayanan medis dokter spesialis kulit dan kelamin dikatakan pemberian deksametason 4-6 x 5 $\mathrm{mg} /$ hari, dan setelah masa kritis diatasi (2-3 hari) dosis diturunkan dengan cepat (5 $\mathrm{mg} / \mathrm{hari}$ ), dan setelah dosis rendah dapat 
diganti peroral (prednison $2 \times 20 \mathrm{mg}$ ). Antibiotik hendaknya dipilih yang jarang menyebabkan alergi dan berspektrum luas. $^{10,12}$ Penatalaksanaan pada pasien ini ialah dengan menghentikan penggunaan obat-obatan yang diduga sebagai penyebab (kotrimoksasol), penanganan suportif berupa IVFD RL:D 5\%:NaCl $0,9 \% \quad(1: 1: 1) \quad 20$ tetes/menit, injeksi ranitidin $2 \times 25 \mathrm{mg}$ IV, injeksi seftriakson $1 \times 2$ gr IV, kompres terbuka $\mathrm{NaCl} 0,9 \% 3 \times 30$ menit pada luka di bibir, serta pemberian imunospuresan berupa deksametason injeksi 4x10 mg IV dengan tappering cepat setiap hari. Pasien juga dikonsulkan ke Bagian Ilmu Penyakit Mata dan THT-KL. Hasil konsultasi dari Bagian Ilmu Penyakit Mata didapatkan konjungtiva hiperemis pada kedua mata dan diberikan penanganan berupa Cendo lyteers ${ }^{\circledR} \quad 6 x 1$ tetes ODS dan Polydex ${ }^{\circledR}$ $4 \times 1$ tetes ODS. Dari Bagian Ilmu Penyakit THT-KL didapatkan faringitis tanpa penanganan khusus.

Kasus ini awalnya didiagnosis banding dengan SSJ tetapi diagnosis SSJ dapat disingkirkan berdasarkan pemeriksaan klinis. Pada SSJ terdapat epidermolisis sebesar $<10 \%$, sedangkan pada NET $>30 \%$.

Prognosis pasien NET dapat diperkirakan berdasarkan penghitungan SCORTEN. Pada kasus ini SCORTEN tidak dapat dihitung karena ketidaktersediaan reagen untuk pengukuran kadar bikarbonat serum. Keadaan umum pasien membaik dalam 2 minggu setelah dilakukan penghentian obat yang diduga penyebab, penanganan suportif, dan pengobatan spesifik. Prognosis pasien ini ialah quo ad vitam, functionam, sanationam dubia ad bonam.

\section{DAFTAR PUSTAKA}

1. Valeyrie-Allanore L, Roujeau JC. Epidermal necrolysis (Steven-Johnson syndrome and toxic epidermal necrolysis). In: Goldsmith LA, Katz SI, Gilchrest, Paller AS, Leffell DJ, Wolff K, editors. Fitzpatrick's Dermatology in General Medicine (8th ed). New York: McGraw Hill, 2012; p. 439-48.

2. Effendi EH. Nekrolisis epidermal toksik. In: Menaldi SL, Bramono K, Indriatimi W, editors. Ilmu Penyakit Kulit dan
Kelamin (7th ed). Jakarta: FK UI, 2015; p.199-200.

3. Wolf R, Davidovici BB. Severe, acute adverse cutaneous drug reaction I: StevenJohnson syndrome and toxic epidermal necrolysis. In: Wolf R, Davidovici BB, Parish JL, Parish LC, editors. Emergency Dermatology. New York: Cambridge University Press, 2010; p. 154-61.

4. Bagian Rekam Medik RSUP Prof. Dr. R. D. Kandou Manado. Data rekam medik Rawat Inap Irina F Kulit dan Kelamin tahun 2012-2014.

5. Bullous drug reactions Steven-Johnson syndrome (SJS) and toxic epidermal necrolysis (TEN)). In: James WD, Berger TG, Elson DM, Neuhaus IM, editors. Andrew's Diseases of the Skin Clinical Dermatology (12th ed). Philadelphia: Elsevier, 2016. p.115-7.

6. French LE, Prins C. Erythema multiforme, Stevens-Johnson syndrome and toxic epidermal necrolysis. In: Bolognia JL, Jorizzo JL, Rapini RP, et al, editors. Dermatology (3rd ed). China: Elsevier, 2012; p. 323-30.

7. Breathnach SM. Erythema multiforme, Stevens-Johnsons syndrome and toxic epidermal necrolysis. In: Burns $\mathrm{T}$, Breathnach S, Cox N, Griffiths C, editors. Rook's Textbook of Dermatology (8th ed). Singapore: Willey-Blackwell Publishing, 2010; p. 76.8-22.

8. Wang WL, Lazar A. Lichenoid and interface dermatitis. In: Calonje E, Brenn T, Lazar A, McKee PH, editors. McKee's Pathology of the Skin (4th ed). China: Elsevier, 2012; p. 219-58.

9. Djuanda A, Hamzah M. Nekrolisis epidermal toksik. In: Djuanda A, Hamzah M, Aisah S, editors. Ilmu Penyakit Kulit dan Kelamin (6th ed). Jakarta: FK UI, 2011; p.166-8.

10. Lehloenya R. Management of StevenJohnson Syndrome and toxic epidermal necrolysis. [cited 2015 June 15]. Available from: http://www.allergysa.org/Content/Journ als/August2007/Management of Stevens-Johnson syndrome and toxic epidermal necrolysis.pdf.

11. Roongpisuthipong W, Prompongsa S, Klangjareonchai T. Retrospective 
analysis of corticosteroid treatment in Steven-Johnson Syndrome and/or toxic epidermal necrolysis over a period of 10 years in Vajira Hospital, Navamindradhiraj University, Bangkok. [cited 2015 June 15]. Available from: http://www.hindawi.com/journals/drp/2
014/237821/.

12. Suriadiredja A, Toruan TL, Widaty S, Listyawan MY, Siswati AS, Danarti R, Rosita C, Nopriyanti. Nekrolisis epidermal toksik. Panduan Pelayanan Medis Dokter Spesialis Kulit dan Kelamin. Jakarta: PERDOSKI, 2014; p. 313-6. 